\title{
Allmennmedisinsk brøkregning
}

\author{
Helse Finnmark har fått my medisinsk fagsjef. Valget falt på Harald G. Sunde, som har 26 års \\ erfaring som allmennlege i Sør-Varanger. Er det mangelen på gode kandidater i egne rekker \\ som var utslagsgivende for denne ansettelsen, eller kan det være slik at allmennleger har et \\ perspektiv på spesialisthelsetjenesten som kan være nyttig å tilføre organisasjonen? Dette \\ spørsmålet var nok til å be om dobbelttime hos legen som enn så lenge har én fot i hver leir.
}

Harald Sunde foreslo at vi skulle treffes på The Dubliner, en irsk pub i Oslo sentrum. At Irland har en stor plass i Harald G. Sundes hjerte, skyldes at han studerte medisin i Dublin i 1970- og 80-årene. Studietiden og stedet vi studerte har en solid plass i våre hjerter ad modum Ibsen: Evig eies kun det tapte.

- Jeg forklarte pubeieren at jeg skulle intervjues og ønsket å ha et irskinspirert miljø som bakgrunn. «Ja, irer er som nordlendinger, så da er nok du som bor i Kirkenes i ditt rette element hos oss,» svarte han meg, forteller Harald Sunde entusiastisk da vi møttes.

- Da jeg kom til Dublin fra min fødeby Oslo i 1977, var det et kultursjokk - irer er et folkeferd som lever i nuet. $\AA$ flytte fra Dublin til Finnmark seks år senere avslørte langt mindre kulturforskjeller, ettersom folk i nord har mange sosiale fellestrekk med irene.

For meg ble et dårlig turnusnummer avgjørende for mitt livsløp. I Kirkenes fant jeg kvinnen som jeg fortsatt er gift med. Våre jobbkarrierer har vært allmennmedisin for meg, hun er psykomotorisk fysioterapeut. Faglig sett har dette vært flott for oss fordi vi jo har innsikt i problemstillingene den andre jobber med. Min kone er den som har lært meg å være til stede der jeg er. Hun drar meg ned på jorden når mine luftige tanker og ville ideer drar meg ut på de store viddene og får meg til å glemme at livet er det vi opplever her og nå, ikke høyt opp og langt frem!

\section{Allmennmedisinsk brøkregning}

- Du har en idé om at allmennmedisinen kan ses som en brøk. Dette må du forklare nærmere!

- En brøk har, som de fleste husker, teller og nevner. Vi leger lærer å sette søkelys på den enkelte pasient, som i min brøkregning er telleren. Samfunnet rundt er nevneren, og den har jo ulik verdi alt etter som hva vi definerer som nevner. Hvis vi tenker tilbake på vår dramatiske krigshistorie, ble en motstandsmann i Sør-Norge automatisk sett på som beste sort nordmann, som en samfunnsstøtte av dimensjoner. En motstandsmann i Finnmark gjorde ofte en vel så stor innsats med like høy risiko, men av geografiske og politiske årsaker var det jo naturlig for ham å samarbeide med russerne. Ved å støtte det kommunistiske Sovjetunionens kamp mot nazistene risikerte han å bli erklært som folkefiende i Norge etter krigen.

Harald Sunde forteller at det var yrkesforbud for kommunister i gruveselskapet AS Sydvaranger allerede tidlig i 1950årene. Her kommer da nevneren inn.

- Nevneren er en faktor enkeltindividet ikke har kontroll over, og den får jo ofte veldig stor betydning for livskvaliteten vår.

\section{«Kunnskap om lokal- samfunnet beriker mitt sinn og gjør meg til en bedre lege»}

Derfor tenker jeg at dersom man ikke kjenner nevneren i brøken, gjør man en mindre god jobb som lege, sier Harald Sunde.

- Kunnskap om lokalsamfunnet beriker mitt sinn og gjør meg til en bedre lege, sier han, og fortsetter: - Dette med brøkregning $i$ allmennmedisinen gjelder mer enn lokalhistorisk kunnskap. Språk, minoriteters kulturbakgrunn og andre forhold i samfunnet er også noe vi leger bør bruke tid på å lære mer om. I Finnmark snakkes det samisk, kvensk og russisk i tillegg til norsk, og det har gjort at jeg er blitt glad i språk. Å beherske litt samisk og ta imot pasientene på deres eget språk åpner dører for en god samtale i konsultasjonen, selv om vi etter hvert går over til norsk. Finsk og russisk behersker jeg ikke bedre enn at jeg knapt kan bløffe meg til noen setninger.

\section{Lokalhistorie}

Vi er nå inne på en av Harald Sundes hovedinteresser, lokalhistorie. Han forteller at det å bo i Sør-Varanger gir enorme muligheter for å lære mye om nevneren i den allmennmedisinske brøken.

- Vi har en spennende gruvehistorie her i Kirkenes, hele byens historie er basert på den. Så har vi kontakten med russerne. Den var omtrent lik null - med hermetisk lukkede grenser før 1991. Om ikke lenge innføres grenseboerbeviset, som gir alle som bor inntil 30 kilometer fra grensen rett til å ferdes fritt inntil 30 kilometer på den andre siden av grensen.

I dag er det 100 000-200 000 passeringer per år over grensen til Russland, om få år regner man med at det kan bli så mye som 400000 grensepasseringer. Mange av dem som kommer over fra Russland i dag er middelklassemennesker på handletur til Kirkenes - utvalg, pris og kvalitet gjør at mange foretrekker å handle i Norge. Harald Sunde forteller at Helse Finnmark bevisst har lagt det nye sykehuset i Kirkenes, som skal stå ferdig i 2018, på en tomt der man kan bygge ut dersom behovet skulle vise seg å være større enn det er i dag.

- Det er ca. 30000 innbyggere i nedslagsfeltet for sykehuset, men det bor 500000 mennesker på russisk side. I fremtiden kan det jo hende de velger å benytte seg av våre tjenester. Nevneren i brøken vår er altså i konstant bevegelse, verdenspolitikken har stor betydning for hvordan vi i vår lille by har det.

\section{Å stå på scenen}

- Som mulig avtroppende allmennlege ser du deg sikkert tilbake. Hva har disse 26 årene egentlig handlet om?

- Å være allmennlege er på mange måter som å stå på scenen. Når de Rema-ansatte går fra lageret til butikken, ser de et stort oppslag: «Husk at du nå går på scenen.» Dette kunne vi med fordel overført til helsetjenesten. Med 20 konsultasjoner per dag er jeg på scenen 80 ganger i uken, i tillegg kommer alle andre møter som også krever at jeg behersker scenekunsten. Jeg liker å stå på scenen. Det koster en del, men det smaker mer enn det koster. Kostnaden er først og fremst det å klare å leve med at våre feil har store konsekvenser for pasientene. Det sies at alle leger har sin lille kirkegård. Vi har et 


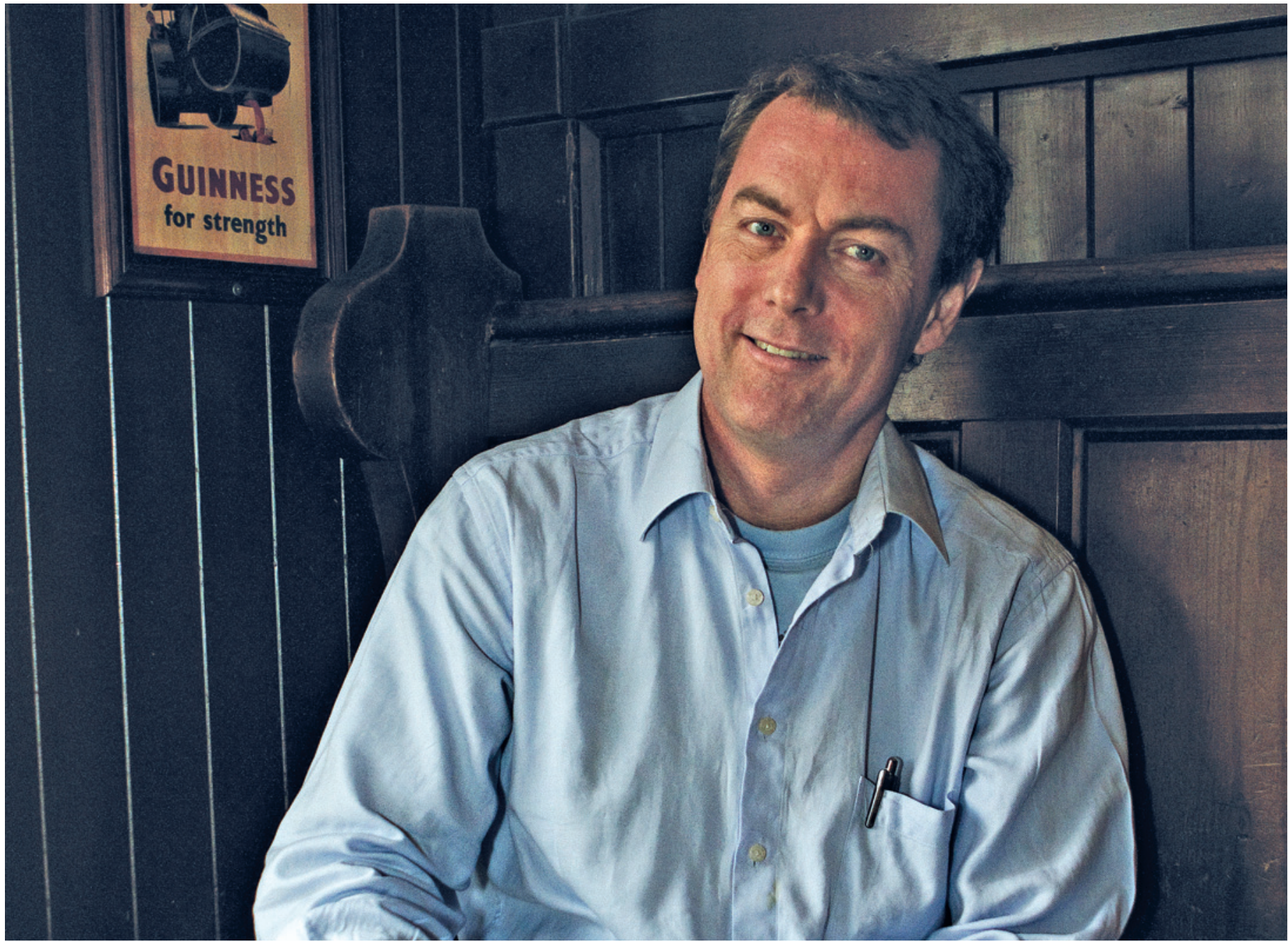

Foto Einar Nilsen

\section{Harald Gunnar Sunde}

Født 1957 i Oslo

- Gift med Merete Pettersen

- Cand.med. fra the Royal College of Surgeons, Irland, 1983

- Spesialist i allmennmedisin 1992

- Allmennlege og fastlege I Kirkenes $1985-2011$

- Medisinsk fagsjef i Helse Finnmark fra 2011 stort ansvar for å sikre at den blir så liten som mulig. Jeg tror vi kan lære å legge ting bak oss og se fremover. At man har gjort en feil, kan ikke prege deg resten av livet, da blir det ikke mulig å gjøre en ansvarlig jobb. - Våre feil er gjerne noe vi tar med oss i det stille. Det kan ofte være vanskelig å få luftet tanker og følelser rundt dette, og mange leger velger derfor å leve med det alene. Har du noen tanker om hvordan man skal håndtere sine feil?

- Tja, nå må jeg tenke - jeg har jo ingen mal som passer inn i hvert tilfelle, det er vel dialogen med pasienten i etterkant som blir det viktigste. Jeg tror vi bør legge oss flate der det er riktig. Men vi må ikke glemme at det i etterpåklokskapens lys er lettere å se hvordan ting burde vært gjort. Fasiten ligger ofte ikke oppe i dagen underveis. Det handler om hvor vi har oppmerksomheten. Jeg lærer mye av bikkja mi, Abbey. Når vi går tur og treffer en annen hund, har hun all oppmerksomhet på den, men når vi har passert den, er den glemt. Abbey skifter oppmerksomhet utrolig fort og ser alltid frem- over. Det jeg har lært, er at du ikke skal grave deg ned i det som har vært, det må du gjøre deg ferdig med. Legg merke til at jeg ikke sier du skal dekke over noe, men at det er i fremtiden vi skal leve - det er der vi skal bruke kreftene. Debriefing og kvalitetssikring er metoder som hjelper oss til dette, sier han og smører inn hendene for fjerde gang under intervjuet. - Jeg er atopiker, og vi er jo ofte litt hektiske mennesker. Kløe gjør oss urolige - du kan nesten kalle det å ha et atopisk sinnelag. - Ja, atopi har ført deg ut i forskningens irrganger. På mange måter ble vel det nok en nevner i din allmennmedisinske brøk?

- Ja, jeg oppdaget at vi på kort tid hadde sju krefttilfeller i en liten bygd med 500 innbyggere og tenkte at dette kunne jo ikke være tilfeldig. Vår nærmeste nabo er nikkelverket i Nikel, der det er store områder med avsvidd skog rundt byen. Jeg tenkte at vi som bodde på norsk side, neppe slapp unna negative helsekonsekvenser av dette. Mange har jo nikkelallergi, så vi valgte å forske på dette.

Det ble etablert en norsk-russisk helse- 
gruppe som registrerte forekomsten av nikkelallergi i Sør-Varanger, Tromsø og Nikel. I Sør-Varanger hadde $25 \%$ av befolkningen nikkelallergi, tallene for Nikel og Tromsø var henholdsvis $5 \%$ og $30 \%$.

- Det var en stor overraskelse for oss at tallene var stikk motsatt av det vi hadde forventet. Det kan altså se ut som eksponering for nikkel via luft gjør russerne immune mot nikkelallergi, som jo bryter ut etter direkte hudkontakt med metallet. Dette viser at en feil tanke kan utløse forskning som gir overraskende resultater. Naturen lider under forurensingen fra nikkelverket, men det ser ut som menneskene tåler den godt.

\section{A skifte scene}

- De siste månedene har du skiftet scene, bokstavelig talt. Nå er du medisinsk fagsjef i Helse Finnmark, en jobb du fikk uten å ha noen bakgrunn fra spesialisthelsetjenesten.

- Ja, noen var nok skeptiske til at jeg fikk stillingen, men jeg mener at jeg kan gjøre en god jobb fordi jeg har stor erfaring som bestiller av spesialisthelsetjenester. Jeg vet hva de - nei, vi ... Han avbryter seg selv: - Jeg er i en overgangsfase, hører du, jeg har ikke landet helt på at $v i$ er de jeg nå har som arbeidsgiver. I over 25 år har jo vi vært primærhelsetjenesten for meg, jeg sitter nok der i stor grad ennå.

Så finner han tilbake til sporet: - Men altså, jeg vet hva primærhelsetjenesten trenger på de ulike områdene. Jeg kjenner grunnplanet. Dette er etter mitt syn et godt utgangspunkt for det arbeidet jeg nå skal gjøre.

Og så legger han til med et selvsikkert smil: - Som jeg har sagt før, jeg liker å stå på scenen. Jeg er en praktiker som håper jeg kan bidra til å bringe Helse Finnmark fremover. Jeg er jo nå kastet ut av komfortsonen fra å være fastlege til å bli helsebyråkrat helt og fullt.

Vi konstaterer at Helse Finnmarks medisinske fagsjef ikke sliter med mindreverdighetskomplekser etter 26 år som allmennlege. Tvert imot, hans vyer skal løfte spesialisthelsetjenesten til de høyder primærhelsetjenesten forventer! Igjen kan vi se at nevneren står i sentrum, nå i utvidet forstand. Han vet at han kan mye om regionen, han har følt på kroppen hva som svikter på grunnplanet.

- Øyelegedekningen er slik organisert at vi har tre øyeleger som det koster Helse Finnmark 4-5 millioner å drifte. Samtidig betaler vi nesten 20 millioner kroner i reiseutgifter for øyepasienter som behandles i Tromsø. Hele $13 \%$ av totalbudsjettet vårt er faktisk billettutgifter, og da er ikke ambulanse- og luftambulansekostnadene tatt med. Hadde vi håndtert øyepasientene våre i Finnmark i stedet for å sende dem til Tromsø, hadde vi hatt 13 millioner kroner i innsparte billettutgifter. Du kan ansette mange øyeleger for den summen. Dette vil bli en vinn-vinn-situasjon, vi sparer penger - finnmarkingene får kortere reiseavstand til øyelegen sin.

\section{NEON i stedet for LEON}

Atopikeren smører hendene nok en gang og tar ut mye hudkløe i sin iver etter å vise at man kan tenke nytt - nå i god samhandlingsånd.

- LEON-prinsippet er en stygg og ukollegial tanke slik jeg ser det, sier Sunde. (Intervjuers anmerkning: LEON er et akronym for Laveste Effektive OmsorgsNivå - et begrep man med varierende hell har prøvd å styre helsetjenesten etter siden 1980-årene.)

- Har du tenkt på hvor galt dette begrepet er? spør han og setter meg sjakk matt: - Tja, jeg vet ikke helt, er ikke det en god idé, da? er alt jeg rekker å skyte inn før kanonaden fortsetter: - Vi i Finnmark skal jobbe etter NEON-prinsippet, som står for «ncermeste

\section{«Å være allmennlege er på mange måter som å stå på scenen»}

effektive omsorgsnivå». Her er det ikke slik at allmennlegene står lavest - de er jo nærmest pasienten. De er fullverdige samarbeidspartnere for spesialisthelsetjenesten, som ikke skal oppfatte seg som på et høyere nivå.

- Dette er jo et spennende utgangspunkt for den nye samhandlingsreformen - nå er det nærmest obligatorisk å spørre deg om hva du tenker om den.

- Samhandlingsreformen blir ingen revolusjon i Finnmark. Jeg ser ikke at de største utfordringene ligger i skjæringspunktet mellom mellom Helse Finnmark og Finnmarks-kommunene, her har samarbeidet fungert veldig godt i mange år. Med sykestuer spredt rundt $\mathrm{i}$ de fleste kommunene er vi godt forberedt på de endringene samhandlingsreformen legger opp til.

- Hva med pasientansvaret? I mange kommuner er jo sykehjemmene små, med tilsynsbesøk av lege noen ganger per uke. Fastlegene vil jo opparbeide liten erfaring med litt kompliserte tilfeller fordi de får så begrenset pasientgrunnlag. Tilgjengelighet til laboratoriemålinger og røntgen er dårlig i mange små kommuner. Er det virkelig en god tanke at allmennlegene skal ha det fulle medisinske ansvaret for kompliserte medisinske problemstillinger?

- Det må aldri bli slik at kommuneledelsen prøver å spare penger ved å få legene til å ta det medisinske ansvaret for dårlige pasienter. Retten til å legge inn pasienter legen mener han ikke kan ta ansvaret for, må være ubestridt. Sykeheimslegen kan fort komme i skvis mellom kom- munens ønske om lavere kostnader, sykehusenes ønske om å skrive ut pasienter tidlig og Helsetilsynet, som i etterkant kan kritisere legen for ikke å ha håndtert det medisinske bildet godt nok. Her må legenes autonomi veie tyngst. Allikevel er tanken om å bremse opp mot en stadig større spesialisthelsetjeneste god, det er jo bl.a. det samhandlingsreformen kan brukes til.

\section{Fastlegeforskriften}

Neste snakkis er forslaget til ny fastlegeforskrift. I skrivende stund er mange svært opprørt over forslagene om detaljregulering som vil endre våre arbeidsbetingelser radikalt. Harald Sunde forteller at han opplevde det som en lykkens dag da de åpnet Kirkenes legesenter AS. I tid falt dette sammen med innføring av fastlegeordningen.

- Vi fikk med det lov til å styre vår egen arbeidsdag slik vi fant det hensiktsmessig. Nå slår pendelen tilbake til 1980-årene, da kommunene hadde mer styringsrett over oss. Det er jo rart at man ønsker å endre en ordning alle er tilfreds med - pasientene, kommunene og legene har vel aldri vært så fornøyd som de siste ti årene. Jeg tror at hvis vi blir styrt for mye, vil vi skifte oppmerksomhet fra ønsket om å gjøre en god jobb til hvordan man kan komme seg unna påleggene fra myndighetene.

Han legger tankefullt og litt bekymret til at det virker som noen kolleger flagger næringsdriften sin veldig høyt. - Vi mottar tross alt $80 \%$ av vår inntekt fra det offentlige. Jeg har alltid oppfattet meg selv om en del av det offentlige helsevesen - det har vel med politisk ståsted å gjøre. Vi som begynte i helsevesenet i 1980-årene, har en bagasje derfra som gjør at vi ikke oppfatter oss først og fremst som næringsdrivende, men som leger på oppdrag fra det offentlige.

Han sier at det synes som myndighetene ikke har sett at det er stor forskjell på god dialog med fastlegene og detaljstyring fra byråkrater som aldri har prøvd fastlegehverdagen i virkelighetens verden.

- Myndighetene bør styre oss, men det bør være en ryddig diskusjon i forkant av en ny forskrift. Der har de sviktet grundig med de forslagene de nå har kommet med. De som ønsker mer kontroll over fastlegene, bør for øvrig se litt på hvor de unge vender blikket. Vi utlyste en fastlegestilling nylig og fikk ingen søkere. Til en assistentlegestilling ved kirurgisk avdeling ved Kirkenes sykehus kom det 26 søknader. Det ser ikke ut som det er så attraktivt for de unge å være fastlege. Dersom vi ikke legger til rette for at det føles kjekt å være fastlege, tror jeg de unge skremmes bort fra denne karriereveien.

\section{Jannike Reymert}

jannike.reymert@ntebb.no

Bakklandet legekontor

Namsos 